\title{
A New Framework of Blue Ocean Strategy for Innovation Performance In Manufacturing Sector
}

\author{
Muhammad Shafiq, Rosmaini Tasmin, Muhammad Imran Qureshi, Josu Takala
}

\begin{abstract}
Innovation research has got a very significant value in modern research. Innovation has significantly altered the human life through research-and-development and production of technology, including the outcomes in the economy. Understanding the determinants of innovation is important because innovations establish companies' competitive advantages (Porter, 1992). In contemporary galvanized world, supremacy of new innovation strategies has taken over older strategies. There have been research on the relationship of these business strategies with innovation performance. Blue Ocean Strategy value innovates for the organization and customer. There has been a need to determine the model of BOS which supports innovation performance. But there was a great need of the empirical research on the impacts these strategies make on innovation performance in Malaysian manufacturing industries. As Malaysia is on slide on world innovation index from 31st to 37th in last five years, an alarm for academics, researchers, industry and government. This endeavor meets that objective. A research framework is tested and developed which support innovation performance. This is an empirical study so the hypothesis are formulated. It is a quantitative research study so data was collected from all over the Malaysian manufacturing organizations. PLS is used to predict the model. Results reveal that three of the five BOS constructs enhance innovation performance.
\end{abstract}

Keywords: BOS, Innovation Performance, New Framework

\section{INTRODUCTION}

Growth of organizations are attached to innovation (Terziovski, 2002). Many scholars have discussed stratgeies of innovation (Dasgupta \& Sanyal, 2009; Vinayan, Jayashree, \& Marthandan, 2012) and (Matzler, Bailom, Friedrich von den Eichen, \& Kohler, 2013). Blue Ocean Strategy is well known as a collaborative strategy and got much of the attention in recent past. In this authors attempt to investigate the relationship of BOS with innovation performance in Malaysian manufacturing industry and attempt to develop a model which enhances innovation performance.

\section{LITERATURE REVIEW}

Revised Manuscript Received on April 19, 2019.

Muhammad Shafiq, Assistant Professor, Department of Management Sciences, Muhammad Ali Jinnah University, Karachi Pakistan.

Rosmaini Tasmin, Associate Professor, Faculty of Technology Management and Business, Universiti Tun Hussein Onn Malaysia, Johor Malaysia.

Muhammad Imran Qureshi, Senior Lecturer, Faculty of technology Management and Technoprenurship, Universiti Teknikal Melaaca, Malaysia

Josu Takala, Professor, University of Vaasa, Finland.
This section has literature review of the variables and their relationship.

\subsection{Blue Ocean Strategy and its constructs}

Developing and sustaining competitive edge through different strategies, for example; Miles and Snow's strategy approach, Porter's differentiation and cost, the resourcebased approach of tangible and non-tangible assets, dynamic capabilities (Teece \& Pisano, 1994) and Blue Ocean Strategy of Kim and Mauborgne (2005) have been the focus of the organizations (Grant, 2016). These have helped organizations to a great extent to compete, though in today's difficult business environment where diversification and innovation are very important for growth (Parnell, 2010). Strategic thinking has revolutionized the business and scholars deserve appreciation (Hitt, Ireland, \& Hoskisson, 2012).

The strategy has been developed through centuries to reach the modern organizational stage, as Porter (1996) said that organizational effectiveness is not a strategy. According to Mintzberg (1978), the pattern of decisions for the future of firm was defined as a strategy. Porter (1980) produced his strategy for competitive advantage based on differentiation and cost. Before him, Miles, Snow, Meyer, and Coleman (1978) presented the (prosperous, analyzer, defender, and reactor) strategies for firms growth in competition. Kim \& Mauborgne (2005) shook the strategic research world with the phenomena of making the competition irrelevant. They presented the 'The Blue Ocean Strategy' which has "a specific constant configuration of strategic rationale behind the creation of 'new markets and industries' to create demand rather fighting" (Kim \& Mauborgne, 2005). According to them, competition is irrelevant, and organizations have to swim out of red bloody oceans of competition. There have been many research, appreciation, and critique around the world on Blue Ocean strategy including (Butler, 2008; Lindič, Bavdaž, \& Kovačič, 2012; Rebón, Ocariz, Gerrikagoitia, \& Alzua-Sorzabal, 2015; Wubben, Düsseldorf, \& Batterink, 2012). The big part of the debate revolved around the differences between Red ocean strategies of the competition, and blue ocean strategy of uncontested industries and markets. Blue Ocean strategy created enormous interest among researchers.

Blue Ocean strategy is "a consistent pattern of strategic thinking behind the creation of new markets and industries 
where demand is created rather than fought for and the rule of competition is irrelevant". BOS has five constructs, "Creating New Uncontested Market Space, Making Competition Irrelevant, Creating and Capturing New Demand, Achieving Differentiation and Cost, Breaking Value Cost Tradeoff' (Kim \& Mauborgne, 2005; Kim \& Mauborgne, 2014). These five constructs of BOS are independent variables of the study, representing BOS.

Uncontested market space creation is the foremost concept of BOS, this is important for an organization to move out of existing market crowd, and create a new space to attract customers. Uncontested market space creation is the foremost concept of BOS, this is important for an organization to move out of existing market crowd, and create a new space to attract customers. It is the strategy in which an organization spaces the customer's requirements as the focus of its principles and policies and centers on customers' needs and learning about them (Kim \& Mauborgne, 2014; Song, Wei, \& Wang, 2015).

Making competition irrelevant is the $2^{\text {nd }}$ construct of BOS, as organizations who swim out of the competition to open blue sea are able to get a competitive advantage as competition takes away energies and innovation capability. Competition is the hallmark of red oceans as contemporary business work is crowded as the bloody red ocean (Kim \& Mauborgne, 2014).

'Create and capture New Demand' is another construct of BOS where organizations focus to create new demand, instead of sharing the existing demand. This is very important as organizations do not focus only on existing demand of the market but create new products and services to attract new customers. It helps organization to avoid competition and attract new customers.

'Breaking the Value-Cost Tradeoff' is an important construct of Blue Ocean Strategy as organizations used to increase cost when creating new value. BOS makes organizations able to break this tradeoff and achieve both at the same time. Organizations create values to intact old customers and attract new customers but the provision of value enhances cost for both organization and customers. This construct of BOS helps the organization to create a value which has worth of the cost, and customers attract to pay for it, as cost should not be very high.

The fifth and the last attribute of BOS is to 'Achieve differentiation and cost'. Contrary to Michael porter strategy of differentiation or cost, BOS is 'differentiation' 'and' 'cost' strategy, not only 'differentiation' or 'cost' strategy. This feature of BOS pulls customers towards organizations and helps it to create value for both customers and business. Historically organizations create differentiation but it increases cost but the organization practicing Blue Ocean Strategy though provides new features but at a cost which is satisfactory for customer.

\subsection{Innovation performance}

As stated by (Jiang \& Li, 2009), activities of innovation, for example new products, new services and number of patents define the innovation performance of an organization. Innovation performance displays contribution of product and process innovations to firm performance. It is an imperative way to give competitive advantage to organizations. According to (Lokshin, Van Gils, \& Bauer, 2009), it is identified as exciting capacity of an organization to cultivate new products and services. As (Teece, Pisano, \& Shuen, 1997) explained that, scholars have acknowledged that organizations achieve competitive advantage because of the ability to renew, assimilate and increase present capabilities and continuously develop new capacities. Product innovation is an important process via which organizations transform and establish competencies that are central for staying competitive within the speedy changing business situation (Lokshin et al., 2009).

Innovation is multi-dimensional concept involving several types and strategies (Muhammad Shafiq et al., 2017). Product innovation is defined as the development or use of new components, features and technologies to produce new products. Product innovation has direct effect on firms' business performance (Rauch, Wiklund, Lumpkin, $\&$ Frese, 2009). Process innovation is defined as the improvement to production processes technologies required to produce a product and it is mostly internal of the organization (Reichstein \& Salter, 2006) .

(Johannessen et al., 2001) scale, was used to measure innovation performance which has six dimensions of new products, new services, new methods of production, Opening new markets, new sources of supply, new ways of organizing

\subsection{Relationship of BOS and innovation performance}

As mentioned in (M Shafiq \& Tasmin, 2016; Terziovski, 2002) works, relationship of strategy with innovation is well discussed. As non-innovative and innovative firms have different strategies and capabilities as mentioned by (Tabak \& Barr, 1999) and quoted by (Karabulut, 2015).

The strategy is to create a competitive edge (Porter, 1980). Markets are saturated, knowledgeable purchaser and hurried technological advancements have pressurized organizations to achieve an advantage. Among the prominent themes in strategic management research is the pursuit of competitive edge (Spencer, Joiner, \& Salmon, 2009). A prominent competitive market position can help to be successful in the market. Ahmadi, Iravani, and Mamani (2015) state that strategy is created due to competition around, so the organization should alter its strategy to accommodate the changes in the environment. Though many scholars have studied the association between competition and strategy as highlighted by Singh, Garg, and Deshmukh (2010) and many others also investigated this link (Baines \& Smith, 2003; Chenhall \& Smith, 2003; Zainun Tuanmat \& Smith, 2011). However, the most extensively quoted, verified, complained, and distinguished strategies remain Porter's differentiation and cost, and Miles and Snow's prosperous, analyzer, reactor and defender (Veett, Ghobadian, \& Gallear, 2009). While Resourcebased strategy is also very significant though, it is difficult to avail data on resources from the manufacturing sector.

As relationship of Business strategies with innovation strategies and innovation performance is frequently discussed in literature (Bozkurt \& Kalkan, 2014; 
Damanpour \& Gopalakrishnan, 2001; Tasmin \& Shafiq), while relationship of Blue ocean strategy with innovation and innovation performance has also been discussed by researchers (Alghamdi, 2016; Bourletidis, 2014; BurkhartKriesel, 2006; Düsseldorf \& Wubben, 2012; MAUME; Pitta, 2009; Plesoianu \& Cîrstea, 2011; Muhammad Shafiq et al., 2017; Wubben et al., 2012; C.-C. Yang \& Yang, 2011).

The important reasons to innovativeness are the factors of learning orientation, market orientation and entrepreneurial orientation. Researchers have underlined the prominence of market orientation and learning orientation in developing a competitive advantage. Organizations can create better products to enhance their performance outcomes, revenue, profit and market share when compared with other organizations having less practices to innovate (Hult et al., 2004).

The relationship between competition and innovation performance have been discussed in previous research. Competitor orientation and the customer orientation, are the highlights as the organization's focus and direction towards its competitor or target customers (Gatignon \& Xuereb, 1997; Ozkaya et al., 2015). Incentive to innovate can be less in those markets where competition is high, because the smaller size of operations of the innovator can put a constraint on the benefit it gets from a new technology. Researchers also claim that the chances of bankruptcy enhances for an organization in the more competitive environment (Ozkaya et al., 2015) which seconds Kim \& Mauborgne, 2005) that in the red bloody ocans of competitions, organizations fight for survival and bigger organizations eat the smaller ones, which prompts organizations to innovate and create value for both customers and organizatons to survive and grow. Investment in research and development is increased in less competitive markets as less competition allows an organization to seize a larger pie of benefits. Moreover, less competition provides a more constant platform for an organization to invest in research and development (Cornaggia et al., 2015).

In light of all above discussions in introduction and literature view, below is displayed the model of the study.

\subsection{Research Model Blue Ocean Strategy}

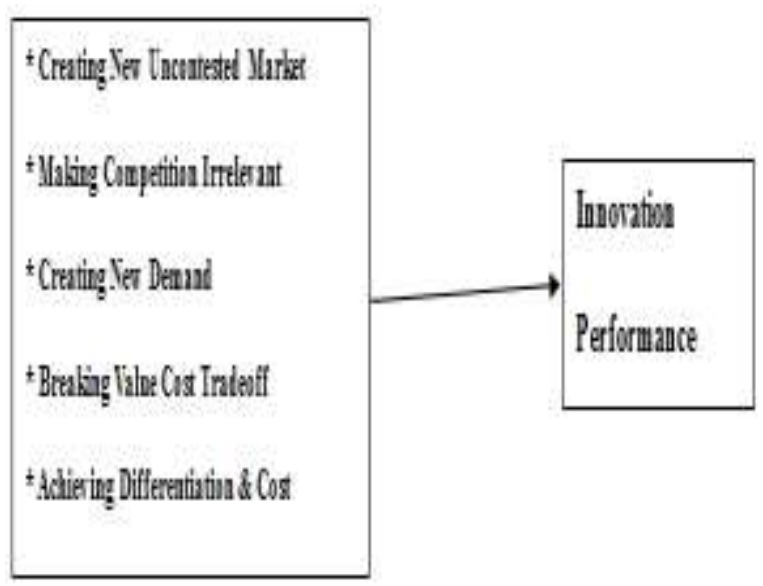

In the light of the above discussion, following hypothesis are formulated.
H1: Blue Ocean Strategy positively impacts innovation performance.

H1a: Creating New Uncontested Market positively impacts innovation performance.

H1b: Making Competition Irrelevant positively impacts innovation performance.

H1c: Creating New Demand positively impacts innovation performance.

H1d: Breaking Value Cost Tradeoff positively impacts innovation performance.

H1e: Achieving Differentiation and Cost positively impacts innovation performance.

\section{METHODOLOGY}

As explained earlier, this is an empirical study which is performed quantitatively by performing appropriate statistical tests. Data was collected used google forms by sending emails to all manufacturing organizations using FMM2017. Response rate was $52 \%$. The study is performed using IBM SPSS 22 and SmartPLS3 for data analysis. Total respondents were 270 for this study.

\section{ANALYSIS AND RESULTS}

First of all, to check the internal consistency reliability of the responses, the Cronbach alpha values were checked. The values for the all variables are shown in the below table. As all values are above 0.80 which is above preferable and very reliable and above the all threshold values mentioned in literature especially (Nunnally, 1978) is comfortable with even 0.70 .

Table2: Reliability

\begin{tabular}{|c|c|c|c|}
\hline Variable & $\begin{array}{l}\text { No } \\
\text { of } \\
\text { Items }\end{array}$ & Behavior & $\begin{array}{l}\text { Cronbach } \\
\text { Alpha }\end{array}$ \\
\hline $\begin{array}{l}\text { Creating New } \\
\text { Uncontested } \\
\text { Market }\end{array}$ & 6 & Independent & 0.840 \\
\hline $\begin{array}{l}\text { Making } \\
\text { Competition } \\
\text { Irrelevant } \\
\text { Creating New } \\
\text { Demand } \\
\text { Breaking Value } \\
\text { Cost Tradeoff } \\
\text { Achieving } \\
\text { Differentiation } \\
\text { and Cost }\end{array}$ & $\begin{array}{l}4 \\
6 \\
8 \\
5\end{array}$ & $\begin{array}{l}\text { Independent } \\
\text { Independent } \\
\text { Independent } \\
\text { Independent }\end{array}$ & $\begin{array}{l}0.812 \\
0.847 \\
0.863 \\
0.845\end{array}$ \\
\hline $\begin{array}{l}\text { Innovation } \\
\text { Performance }\end{array}$ & 5 & Dependent & 0.894 \\
\hline
\end{tabular}


International Conference on Recents Advancements in Engineering and Technology (ICRAET-18) |15th and 16th March 2019|Siddhartha Institute of Technology \& Sciences, Telangana, India.

Table 3 Multicollinearity

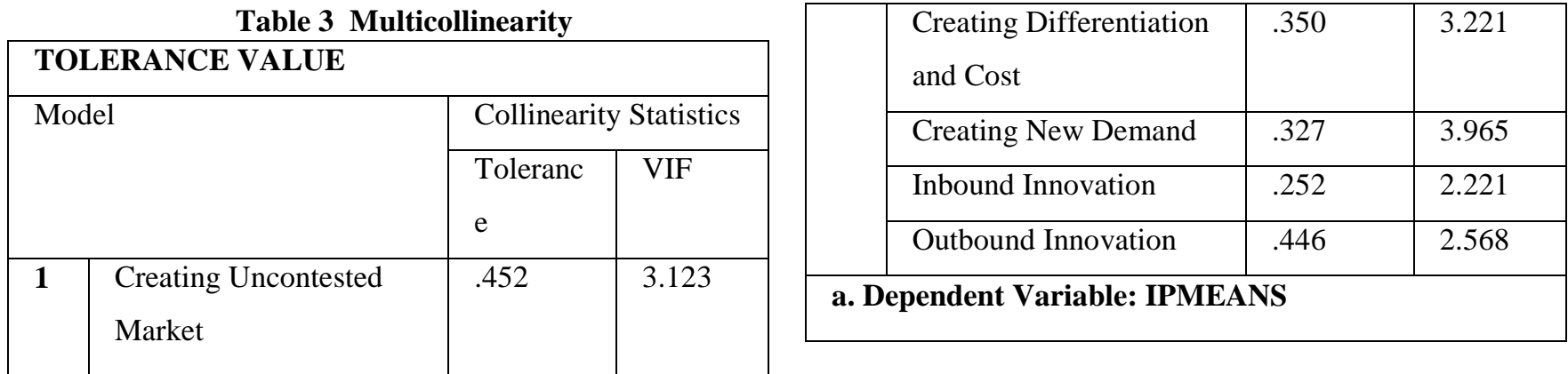

As the values of tolerance are more than 0.10 , this indicates that the multicollinearity assumption was not violated. The VIF values, also less than five which supports the fact that the assumption of multicollinearity is met.

Results of Measurement Model

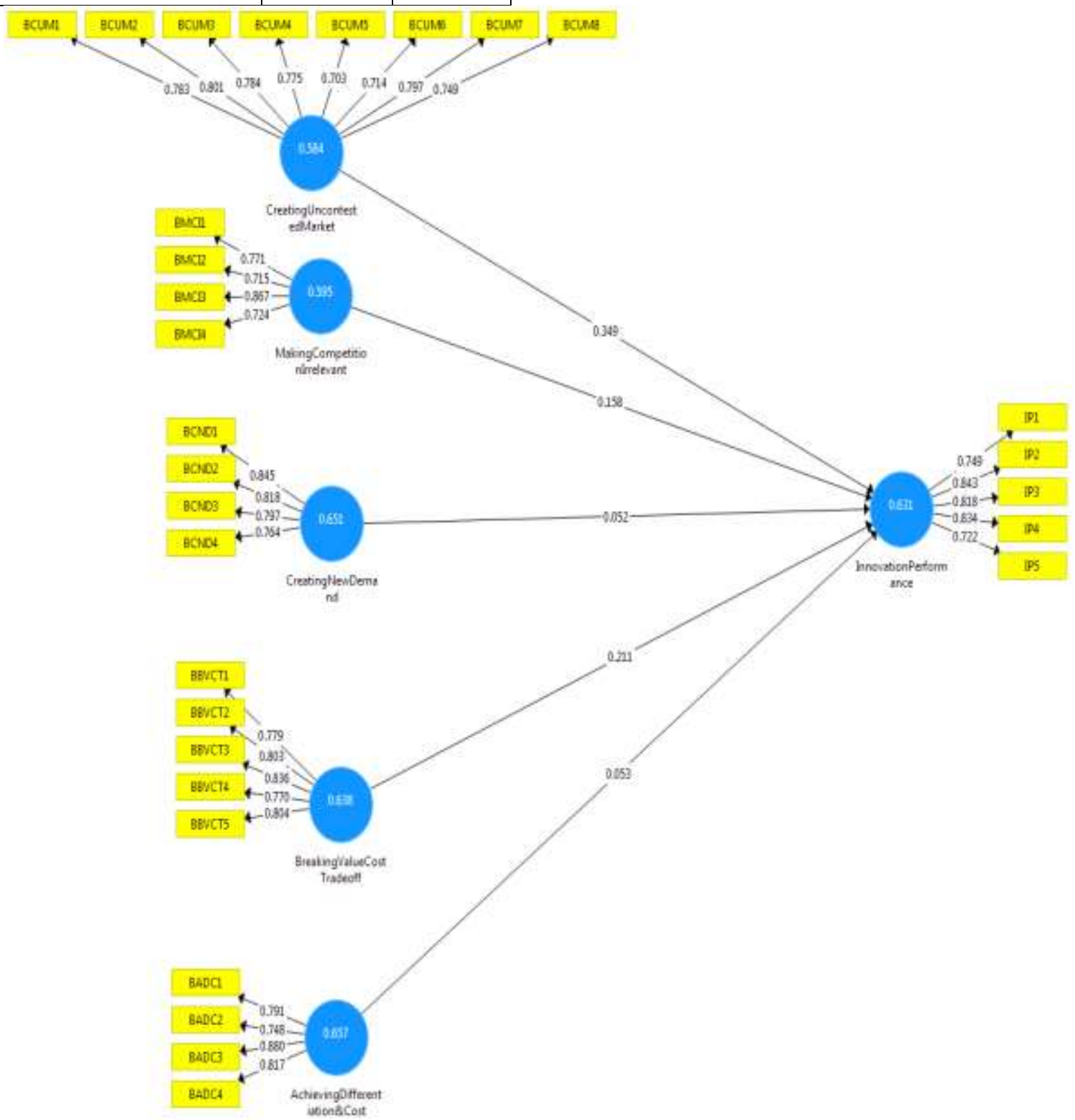


Results of the measure model are presented in the above figure. This shows the relationship of exogenous means independent variables of five BOS constructs with the innovation performance.

The below table reflects the results of the measurement model, achieved after running the algorithm for measurement model in the PLS. This Table 4 is about the construct validity of the constructs of the research, number of items for each construct are represented with their respective factor loadings. While Average variance extract (AVE) for each construct is above 5.0 which is the main condition for construct validity. While composite reliability and cronbach alpha value is also satisfactory, above 0.8 for all constructs.

Table 4 Construct Validity

\begin{tabular}{|c|c|c|c|c|c|}
\hline Constructs & Items & $\begin{array}{l}\text { Factor } \\
\text { Loading }\end{array}$ & AVE & $\begin{array}{l}\text { Composite } \\
\text { Reliability }\end{array}$ & $\begin{array}{l}\text { Cronbach } \\
\text { Alpha }\end{array}$ \\
\hline \multirow{8}{*}{$\begin{array}{l}\text { Creating New } \\
\text { Uncontested Market }\end{array}$} & BCUM1 & 0.764 & \multirow[t]{8}{*}{0.584} & \multirow[t]{8}{*}{0.843} & \multirow[t]{8}{*}{0.856} \\
\hline & BCUM2 & 0.812 & & & \\
\hline & BCUM3 & 0.765 & & & \\
\hline & BCUM4 & 0.767 & & & \\
\hline & BCUM5 & 0.702 & & & \\
\hline & BCUM6 & 0.763 & & & \\
\hline & BCUM7 & 0.756 & & & \\
\hline & BCUM8 & 0.763 & & & \\
\hline \multirow{4}{*}{$\begin{array}{l}\text { Making Competition } \\
\text { Irrelevant }\end{array}$} & BMCI1 & 0.763 & \multirow[t]{4}{*}{0.596} & \multirow[t]{4}{*}{0.845} & \multirow[t]{4}{*}{0.843} \\
\hline & BMCI2 & 0.732 & & & \\
\hline & BMCI3 & 0.854 & & & \\
\hline & BMCI4 & 0.747 & & & \\
\hline \multirow{4}{*}{$\begin{array}{l}\text { Creating New } \\
\text { Demand }\end{array}$} & BCND1 & 0.839 & \multirow[t]{4}{*}{0.651} & \multirow[t]{4}{*}{0.870} & \multirow[t]{4}{*}{0.861} \\
\hline & BCND2 & 0.811 & & & \\
\hline & BCND3 & 0.810 & & & \\
\hline & BCND4 & 0.785 & & & \\
\hline \multirow{5}{*}{$\begin{array}{l}\text { Breaking Value-Cost } \\
\text { Tradeoff }\end{array}$} & BAVCT1 & 0.783 & \multirow[t]{5}{*}{0.638} & \multirow[t]{5}{*}{0.885} & \multirow[t]{5}{*}{0.863} \\
\hline & BAVCT2 & 0.807 & & & \\
\hline & BAVCT3 & 0.831 & & & \\
\hline & BAVCT4 & 0.767 & & & \\
\hline & BAVCT5 & 0.804 & & & \\
\hline \multirow{4}{*}{$\begin{array}{l}\text { Achieving } \\
\text { Differentiation } \\
\& \text { Cost }\end{array}$} & BCDC1 & 0.781 & \multirow[t]{4}{*}{0.658} & \multirow[t]{4}{*}{0.885} & \multirow[t]{4}{*}{0.825} \\
\hline & BCDC2 & 0.763 & & & \\
\hline & BCDC3 & 0.878 & & & \\
\hline & BCDC4 & 0.820 & & & \\
\hline \multirow{5}{*}{$\begin{array}{l}\text { Innovation } \\
\text { Performance }\end{array}$} & IP1 & 0.743 & \multirow[t]{5}{*}{0.631} & \multirow[t]{5}{*}{0.895} & \multirow[t]{5}{*}{0.853} \\
\hline & IP2 & 0.842 & & & \\
\hline & IP3 & 0.817 & & & \\
\hline & IP4 & 0.835 & & & \\
\hline & IP5 & 0.728 & & & \\
\hline
\end{tabular}


International Conference on Recents Advancements in Engineering and Technology (ICRAET-18) |15th and 16th March 2019|Siddhartha Institute of Technology \& Sciences, Telangana, India.

\section{Discriminant validity}

Discriminant validity of the constructs are very important as it shows that all the construct all different to eachother. The HTMT value should be less than 0.85 which shows the correlation of the constructs is not very high. All the values of the constructs inter correlations are less than 0.85 which satisfies the discriminant validity condition, and shows that measurement model is valid for testing.

Table 5 Heterotrait-monotrait ratio (HTMT)

\begin{tabular}{|l|l|l|l|l|l|l|l|l|}
\hline & BVCT & CND & CUM & D\&C & IBI & IP & MCI & OBI \\
\hline Breaking ValueCost Tradeoff & & & & & & & & \\
\hline CreatingNewDemand & 0.750 & & & & & & & \\
\hline CreatingUncontestedMarket & 0.457 & 0.651 & & & & & & \\
\hline Differentiaation\&Cost & 0.762 & 0.778 & 0.462 & & & & & \\
\hline Inbound Innovation & 0.535 & 0.527 & 0.656 & 0.523 & & & & \\
\hline Innovation Performance & 0.593 & 0.626 & 0.725 & 0.559 & 0.640 & & & \\
\hline MakingCompetitionIrrelevant & 0.725 & 0.782 & 0.738 & 0.710 & 0.536 & 0.710 & & \\
\hline Outbound Innovation & 0.438 & 0.495 & 0.469 & 0.329 & 0.651 & 0.471 & 0.611 & \\
\hline
\end{tabular}

Assessment of Direct Relationships

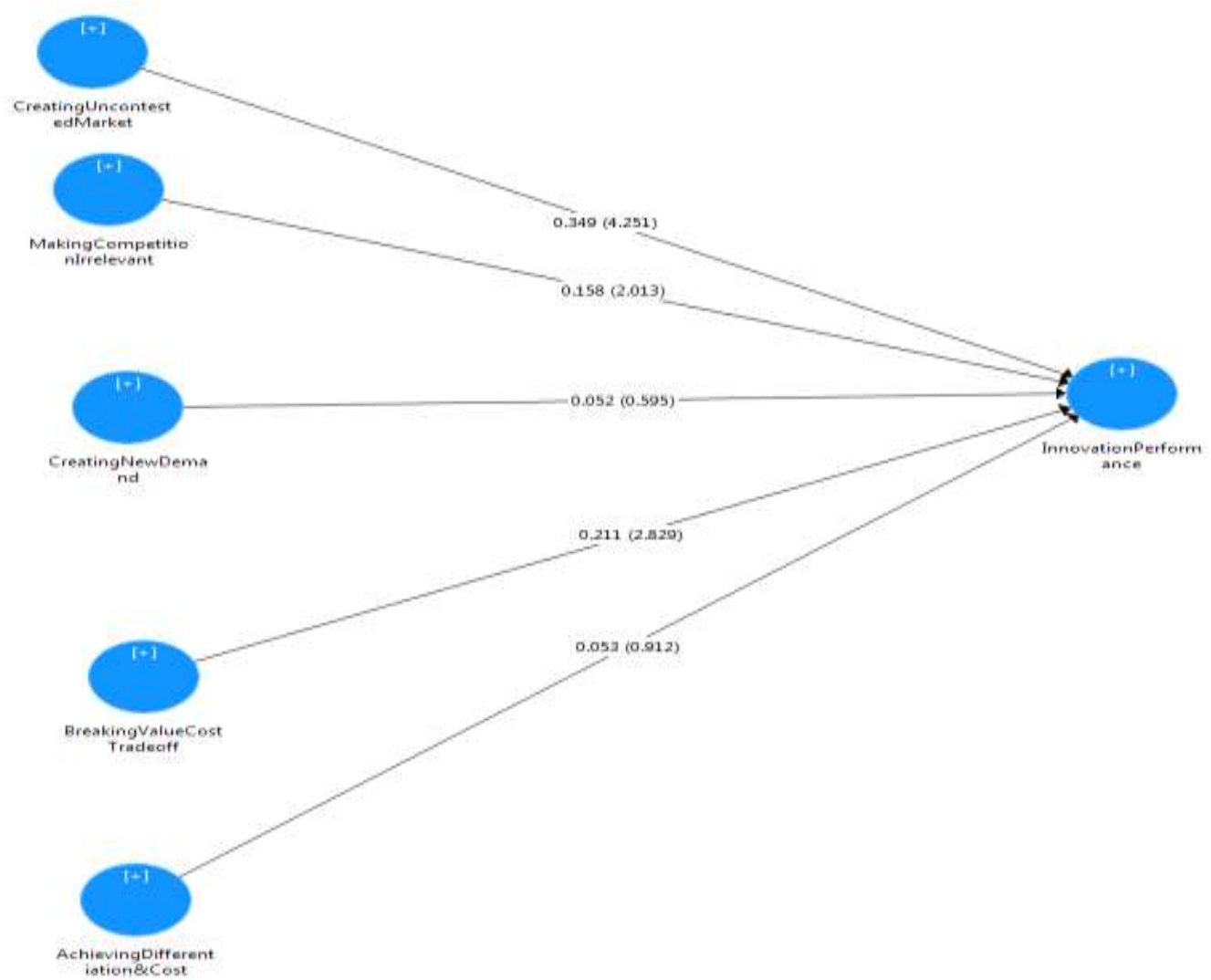


The above figure shows the direct relationship of the exogenous and endogenous variables of the study. Results reveal that only three of the BOS constructs has significant and positive relationship with innovation performance As the cut of value for two tailed directional relationship is 1.64 for at 0.05 confidence level of $p$.

\section{CONCLUSION}

Results of the paper clearly show that three of the BOS constructs creating new uncontested market space, making competition irrelevant and creating new demand significantly and positively impact innovation performance. While creating new demand and achieving differentiation and cost do not have significant and positive relationship in the Malaysian manufacturing industry. So, researcher propose a new updated framework for BOS which is better to enhave innovation performance.

The new proposed model is

Blue Ocean Strategy

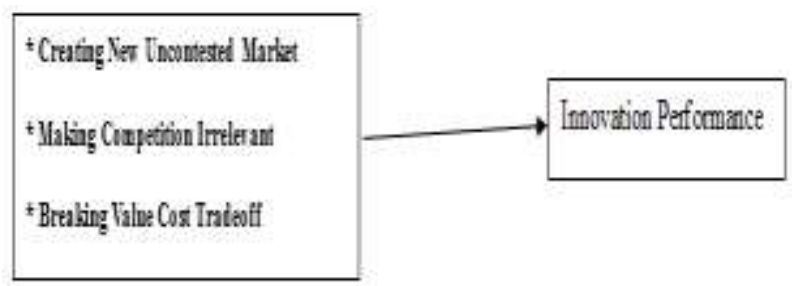

This is very important research and answers important questions for Malaysian industries as innovation performance is very important for better growth and performance of the organization, moreover it contributes towards the overall country's innovation performance as well.

\subsection{Future Work}

This results thought very significant and important for the Malaysian industries, and contributes towards the relational theory in study of organization's collaborations for the better innovation performance. There have been previous research by authors (M Shafiq \& Tasmin, 2016) about the relationships of business strategies with open and close innovations. Authors have already published the research of open innovation strategies as mediators between relationships of different conventional (Muhammad et al., 2017) and modern business strategies (Muhammad Shafiq et al., 2017) with innovation and organizational performances respectively, and some work is in publication. Moreover, this research is only limited to Malaysian industries which can be spread to other countries as well.

\section{ACKNOWLEDGEMENT}

"This paper is sponsored by the Research Management Center (RMC) of Universiti Tun Hussein Onn Malaysia (UTHM), Johor Malaysia"

\section{REFERENCES}

1. Chesbrough, H., Vanhaverbeke, W., \& West, J. (2006). Open innovation: Researching a new paradigm: Oxford University Press on Demand.
2. Chiaroni, D., Chiesa, V., \& Frattini, F. (2011). The Open Innovation Journey: How firms dynamically implement the emerging innovation management paradigm. Technovation, 31(1), 34-43.

3. Christensen, J. F., Olesen, M. H., \& Kjær, J. S. (2005). The industrial dynamics of Open Innovation-Evidence from the transformation of consumer electronics. Research policy, 34(10), 1533-1549.

4. Cohen, J. (1988). Statistical power analysis for the behavioral sciences . Hilsdale. NJ: Lawrence Earlbaum Associates, 2.

5. Dasgupta, S., \& Sanyal, D. (2009). Bridge to the future: connect your strategies in an interconnected world. Foresight, 11(1), 81-93.

6. Dodgson, M., Gann, D., \& Salter, A. J. (2005). Think, play, do: Technology, innovation, and organization: Oxford University Press on Demand.

7. Garcia, R., \& Calantone, R. (2002). A critical look at technological innovation typology and innovativeness terminology: a literature review. Journal of product innovation management, 19(2), 110-132.

8. Gobbo, J. A., \& Olsson, A. (2010). The transformation between exploration and exploitation applied to inventors of packaging innovations. Technovation, 30(5), 322-331.

9. Henkel, J. (2006). Selective revealing in open innovation processes: The case of embedded Linux. Research policy, 35(7), 953-969.

10. Iansiti, M., \& Levien, R. (2004). The keystone advantage: what the new dynamics of business ecosystems mean for strategy, innovation, and sustainability: Harvard Business Press.

11. Jiang, X., \& Li, Y. (2009). An empirical investigation of knowledge management and innovative performance: The case of alliances. Research policy, 38(2), 358-368.

12. Johannessen, J.-A., Olsen, B., \& Lumpkin, G. T. (2001). Innovation as newness: what is new, how new, and new to whom? European Journal of innovation management $4(1), 20-31$.

13. Karabulut, A. T. (2015). Effects of Innovation Strategy on Firm Performance: A Study Conducted on Manufacturing Firms in Turkey. Procedia-Social and Behavioral Sciences, 195, 1338-1347.

14. Laursen, K., \& Salter, A. (2006). Open for innovation: the role of openness in explaining innovation performance among UK manufacturing firms. Strategic management journal, 27(2), 131-150.

15. Leminen, S., Leminen, S., Nyström, A.-G., Nyström, A.G., Westerlund, M., Westerlund, M., . . Kortelainen, M J. (2016). The effect of network structure on radical innovation in living labs. Journal of Business \& Industrial Marketing, 31(6), 743-757.

16. Lokshin, B., Van Gils, A., \& Bauer, E. (2009). Crafting firm competencies to improve innovative performance. European Management Journal, 27(3), 187-196.

17. Matzler, K., Bailom, F., Friedrich von den Eichen, S., \& Kohler, T. (2013). Business model innovation: coffee triumphs for Nespresso. Journal of Business Strategy, 34(2), 30-37.

18. Mayers, A., \& Brenner, Y. (1995). "Make or buy": the potential subversion of corporate strategy-the case of Philips. International Journal of Social Economics, 22(4), 4-11.

19. McIvor, R. T., \& Humphreys, P. K. (2000). A case-based reasoning approach to the make or buy decision. Integrated Manufacturing Systems, 11(5), 295-310. 
20. Muhammad, S., Rosmaini, T., \& Mehwish, R. (2017). Mediating Role of Innovation Strategy Between Porter's Red Ocean Strategy and Innovative Performance. Advanced Science Letters, 23(9), 9239-9242.

21. Nunnally, J. (1978). Psychometric methods: New York: McGraw-Hill.

22. Porter, M. E. (1992). Capital disadvantage: America's failing capital investment system. Harvard Business Review, 70(5), 65-82.

23. Prajogo, D. I., \& Ahmed, P. K. (2007). The relationships between quality, innovation and business performance: An empirical study. International Journal of Business Performance Management, 9(4), 380-405.

24. Rauch, A., Wiklund, J., Lumpkin, G. T., \& Frese, M. (2009). Entrepreneurial orientation and business performance: An assessment of past research and suggestions for the future. Entrepreneurship theory and practice, 33(3), 761-787.

25. Reichstein, T., \& Salter, A. (2006). Investigating the sources of process innovation among UK manufacturing firms. Industrial and Corporate change, 15(4), 653-682.

26. Shafiq, M., \& Tasmin, R. (2016). Linking Business Strategy with Organizational Innovation. INNOVATION AND MANAGEMENT.

27. Shafiq, M., Tasmin, R., Takala, J., Qureshi, M. I., \& Rashid, M. (2017). RELATIONSHIP OF BLUE OCEAN STRATEGY AND INNOVATION PERFORMANCE, AN EMPIRICAL STUDY.

28. Tabak, F., \& Barr, S. H. (1999). Propensity to adopt technological innovations: the impact of personal characteristics and organizational context. Journal of Engineering and Technology Management, 16(3), 247270.

29. Teece, D. J., Pisano, G., \& Shuen, A. (1997). Dynamic capabilities and strategic management. Strategic management journal, 509-533.

30. Terziovski, M. (2002). Achieving performance excellence through an integrated strategy of radical innovation and continuous improvement. Measuring Business Excellence, 6(2), 5-14.

31. Vinayan, G., Jayashree, S., \& Marthandan, G. (2012). Critical success factors of sustainable competitive advantage: A study in Malaysian manufacturing industries. international journal of business and management, 7(22), 29.

32. West, J., \& Gallagher, S. (2006). Challenges of open innovation: the paradox of firm investment in opensource software. $R \& d$ Management, 36(3), 319-331. 